\title{
molecules
}

ISSN 1420-3049

http://www.mdpi.org

\section{Electrochemical and Electrocatalytical Properties of $3,7,13,17$-Tetramethyl-2,8,12,18-Tetrabutylporphyrin in Alkaline Solution}

\author{
Egor G. Girichev ${ }^{1}$, Michail I. Bazanov ${ }^{1}$, Nugzar Zh. Mamardashvili ${ }^{2}$ and A. Gjeyzak ${ }^{1}$ \\ ${ }^{1}$ Ivanovo State University of Chemistry and Technology, 153000, Engels av., 7. Ivanovo, Russian \\ Federation \\ E-mail: girichev@icti.ivanovo.su \\ ${ }^{2}$ Institute of Solution Chemistry of the Russian Academy of Sciences, 153045, Akademicheskaya, 1, \\ Ivanovo, Russian Federation \\ E-mail:ngm@ihnr.polytech.ivanovo.su
}

Received: 17 March 2000 / Accepted: 27 March 2000 / Published: 12 June 2000

\begin{abstract}
The reduction and oxidation behaviour in alkaline solution of 3,7,13,17tetramethyl-2,8,12,18-tetrabutylporphyrin $(\mathbf{L})$ has been studied by cyclic voltammetry. The shape of I-E curves was investigated at different terminal values of electrode potential and at different scan rates. It was shown that it is possible to obtain two reversible one-electron electroreduction processes accompanied by the formation of mono- and dianion forms of the porphyrin under specific experimental conditions. The reduction potentials of the $\mathrm{L}^{\prime} \Leftrightarrow \mathrm{L}^{-}$and $\mathrm{L}^{-} \Leftrightarrow \mathrm{L}^{2-}$ processes are $-0.67 \pm 0.02 \mathrm{~V}$ and $-1.12 \pm 0.02 \mathrm{~V}$, respectively.
\end{abstract}

Keywords: Porphyrin, reduction potential, electroreduction.

\section{Introduction}

There are several publications concerning investigations of the electrochemical and electrocatalytical properties of porphyrin compounds [1-5]. The reasons for this considerable interest in porphyrins and their metal complexes are their semiconductive, photosensitivity and catalytic properties as well as the possibility of modifying these properties by structural modification of the porphyrin ring.

(C) 2000 by MDPI (http://www.mdpi.org). Reproduction is permitted for noncommercial purposes. 
The aim of this work was an investigation of the electrochemical and electrocatalytical properties of 3,7,13,17-tetramethyl-2,8,12,18-tetrabutylporphyrin (L). This article also forms part of a larger body of experimental work concerning macroheterocyclic compounds and their metal complexes in alkaline solution [6-10].

\section{Results and Discussion}

As shown in Fig.1, only one peak IIk $(\mathrm{E}=-1.3 \ldots-1.5 \mathrm{~V})$ can be found on the cathode curve. This curve was obtained after bubbling Ar through the electrolyte for 30 minutes. On the anode curve the inverse process peak IIa is easily detected at $\mathrm{E}=-1.0 \ldots-1.3 \mathrm{~V}$. The ratios between the quantities of electricity as well as the difference between the potentials of peaks IIk and IIa do not correspond to a reversibility of process II. The peaks Ia $(\mathrm{E}=-0.6 \ldots-0.8 \mathrm{~V})$ and IIIa $(0 \ldots 0.2 \mathrm{~V})$ also appear on the anode curve, whereas the corresponding peaks are absent on the cathode curve.

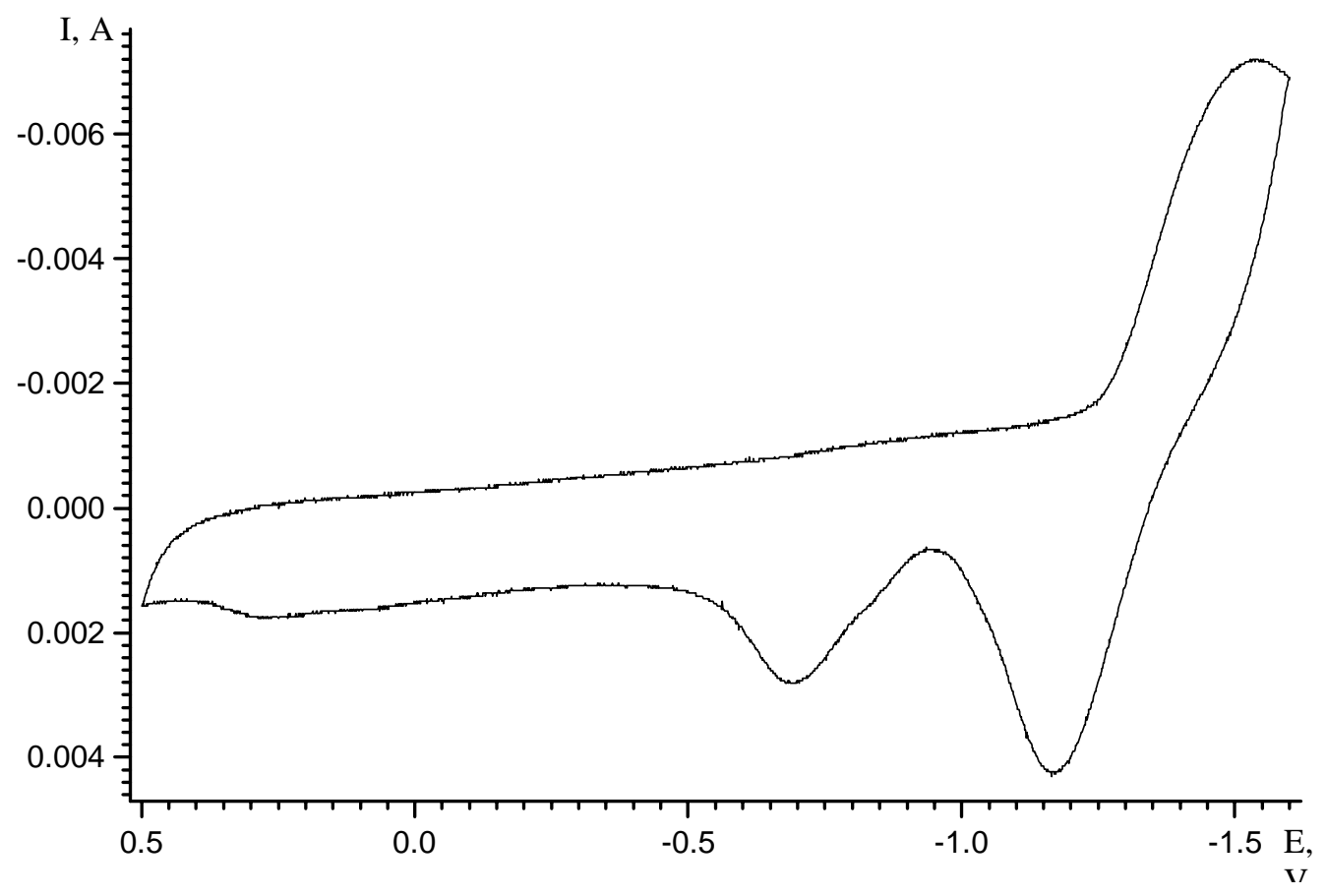

Figure 1. Cyclic voltammogram recorded in oxygen-free $0.1 \mathrm{KOH} . \mathrm{Scan}$ rate $=20 \mathrm{mV} / \mathrm{s}$.

An additional experiment was carried out to obtain the corresponding pairs of peaks Ia and IIIa. A preliminary electroreduction at $\mathrm{E}=0.5 \mathrm{~V}$ and electrooxidation at $\mathrm{E}=-1.6 \mathrm{~V}$ was imposed on the working electrode potential. As shown in Fig.2 the two weak peaks for the process III appear if anode polarization at $\mathrm{E}=0.5 \mathrm{~V}$ is performed. 


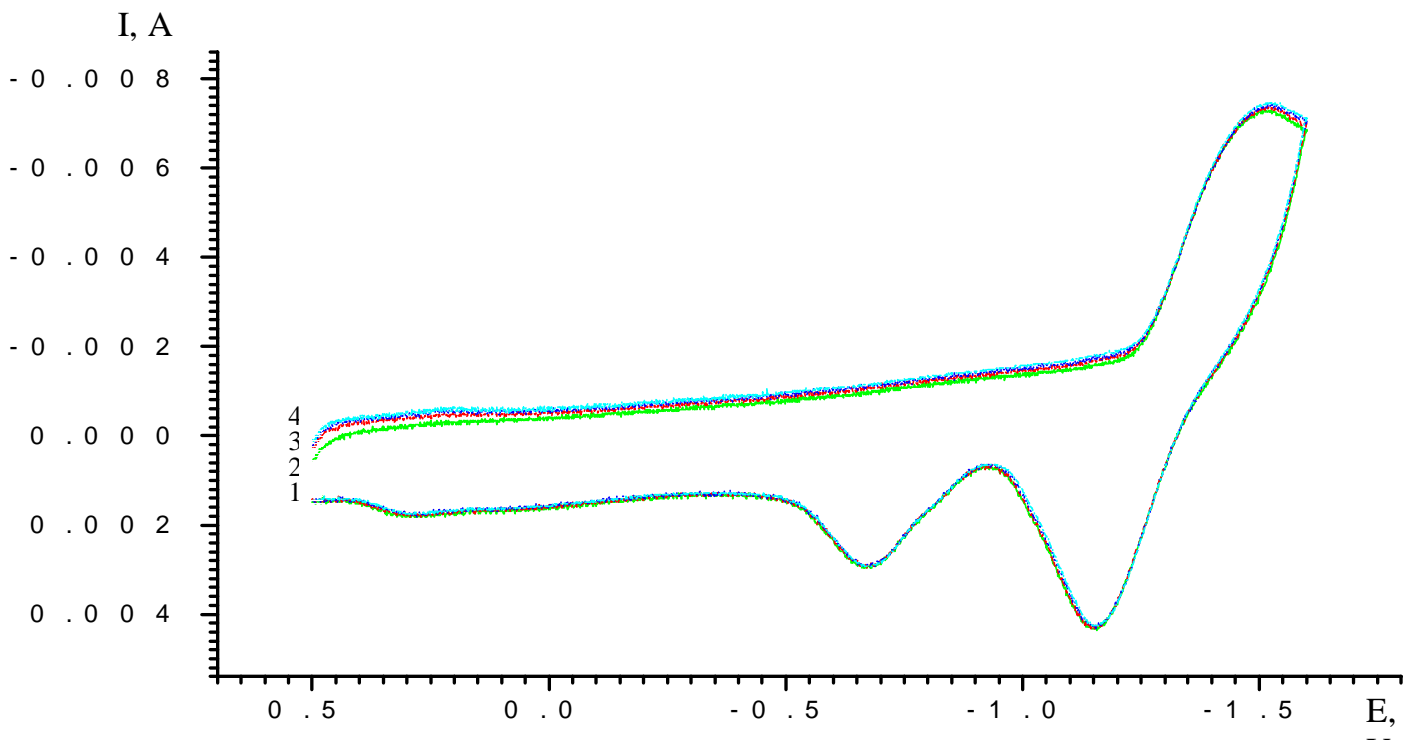

Figure 2. Cyclic voltammogram when eletrode polarization at $\mathrm{E}=0.5 \mathrm{~V}$ is perfomed. Polarization time, s: $1-10 ; 2-50 ; 3-100 ; 4-200$. Scan rate $=20 \mathrm{mV} / \mathrm{s}$.

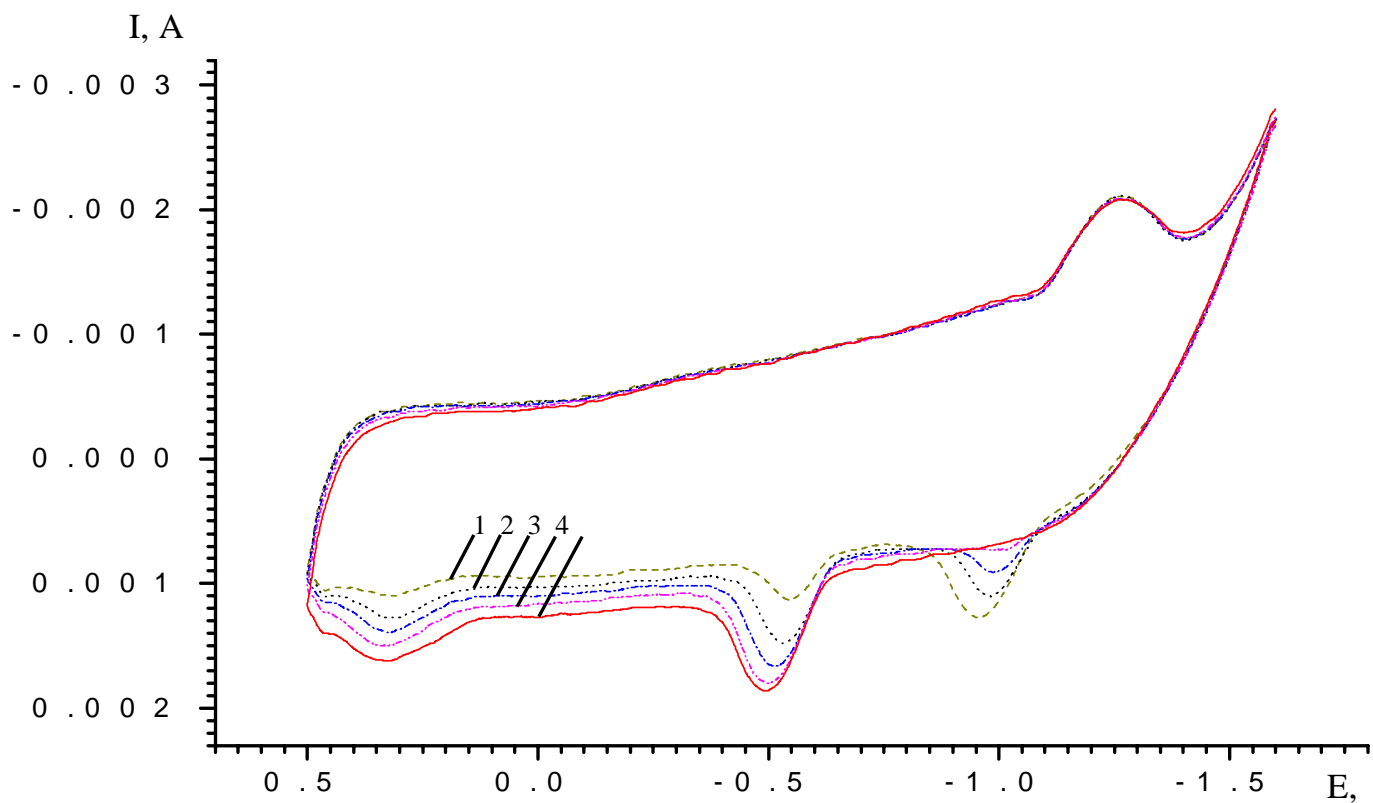

Figure 3. Cyclic voltammogram with electrode polarization at $E=-1.6 \mathrm{~V}$. Polarization time, s: 1-10; 2$50 ; 3-100 ; 4-200 ; 5-500$. Scan rate $=20 \mathrm{mV} / \mathrm{s}$.

Electrode polarization at $-1.6 \mathrm{~V}$ affected the redistribution of the square peaks for the processes I and III (Fig.3). This redistribution depends on the electrode polarization time, and the irreversibility of process II is seen to increase. At the same time the intensity of process I is growing (the area of peak Ia is increasing), but this process is still irreversible. It was thus shown that the shape of the I-E curves depends on the range of the electrode potential change (Fig.4). Increasing the potential from -1.6V to 
more positive values (Fig.4, curves 2-5) causes a decrease of the current intensity.

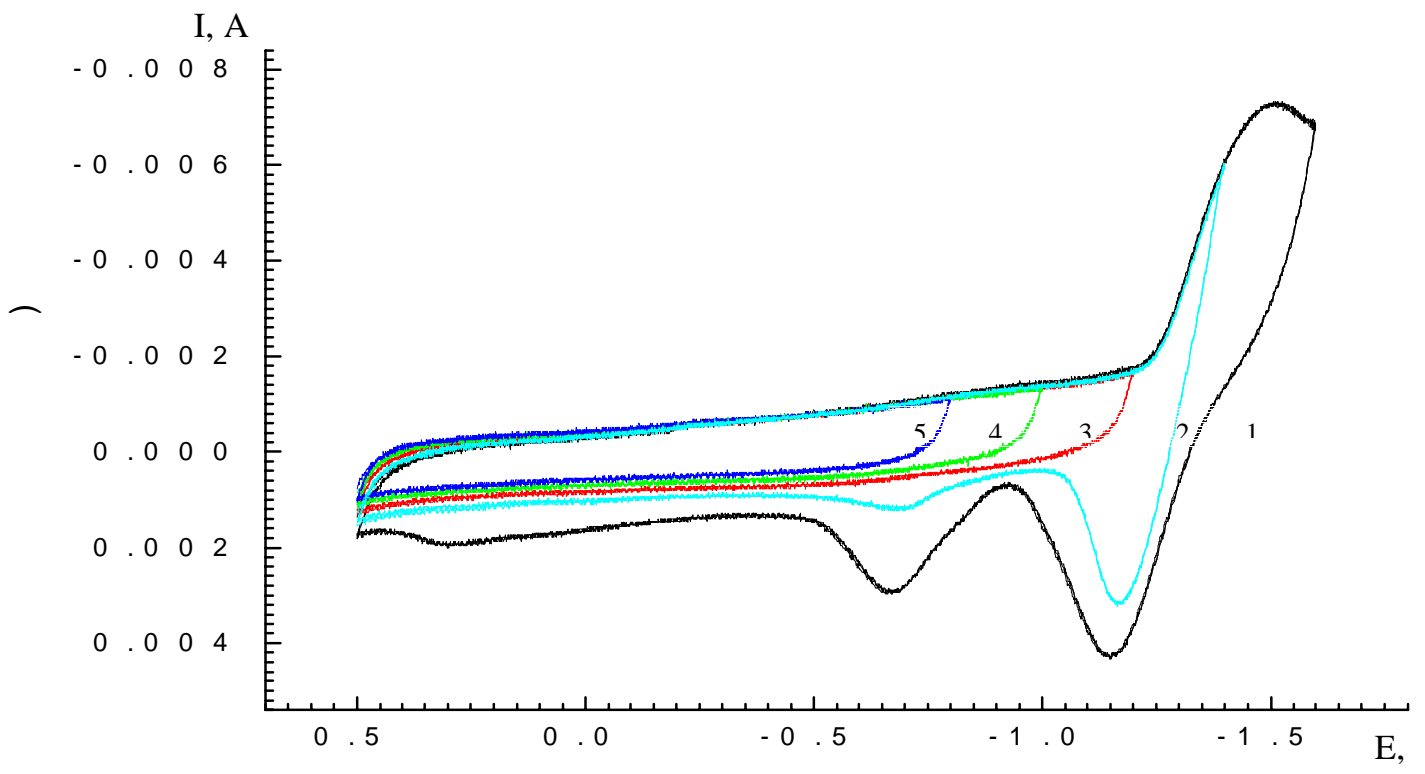

Figure 4. I-E curves depends on the range of the electrode potential changing $(\mathrm{V})(1=-1.6 ; 2=-1.4 ; 3=-$ $1.2 ; 4=-1.0 ; 5=-0.8)$. Scan rate $=20 \mathrm{mV} / \mathrm{s}$.

In Fig. 5 the shapes of the I-E curve at different terminal anode potential values are shown. The cathode peak corresponding to process I appears to narrow the range from $0.5 \mathrm{~V}$ to negative value. The reversibility of the process $I$ is also increasing as the range of the potential narrows.

The existence of the stable I-E curve with two peaks corresponding to one-electron processes allows us to investigate the dependence of peak position and the corresponding quantities of electricity for those processes upon scan rate (Fig.6, Table1).

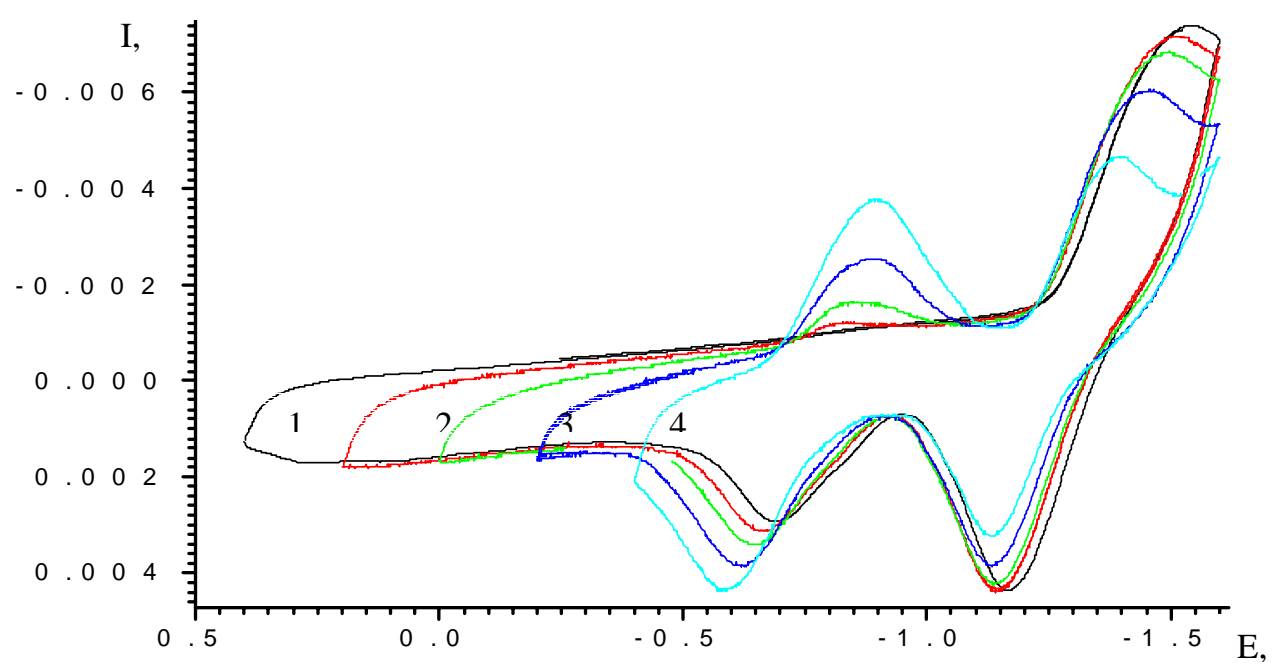

Figure 5. I-E curves dependence on the range of the electrode potential change(V) $(1=0.4 ; 2=0.2 ; 3=0$; $4=-0.2 ; 5=-0.4)$. Scan rate $=20 \mathrm{mV} / \mathrm{s}$. 
The potentials for both oxidation and reduction were obtained by extrapolation of the potentials to zero scan rates. The effective numbers of electrons was calculated as well.

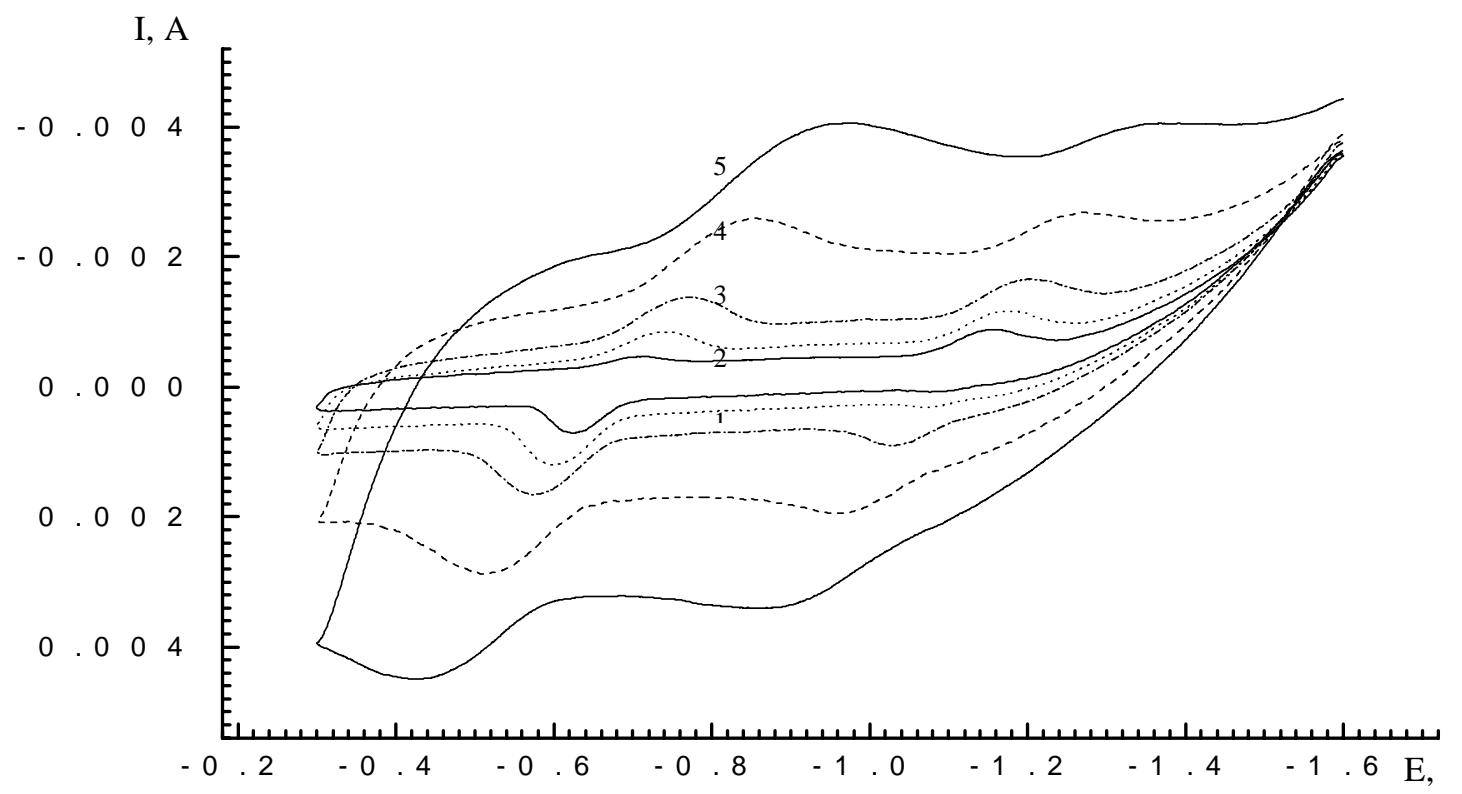

Figure 6. Cyclic voltammogram depends on scan rate. Scan rate (mV/s) 1-5; 2-10; 3-20; 4-50; 5-100.

Table 1. The parameters of electrochemical processes under investigation at the different scan rate.

\begin{tabular}{|c|c|c|c|c|c|c|}
\hline \multirow{2}{*}{ Scan rate, $\mathrm{mV} / \mathrm{s}$} & \multicolumn{3}{|c|}{ Process $\mathrm{I}\left(\mathrm{L} \Leftrightarrow \mathrm{L}^{-}\right)$} & \multicolumn{3}{c|}{ Process $\mathrm{II}\left(\mathrm{L}^{-} \Leftrightarrow \mathrm{L}^{2-}\right)$} \\
\cline { 2 - 8 } & $\mathrm{E}_{\mathrm{k}}, \mathrm{V}$ & $\mathrm{E}_{\mathrm{a}}, \mathrm{V}$ & $\mathrm{E}_{\text {red/ox }}, \mathrm{V}$ & $\mathrm{E}_{\mathrm{k}}, \mathrm{V}$ & $\mathrm{E}_{\mathrm{a}}, \mathrm{V}$ & $\mathrm{E}_{\text {red/ox }}, \mathrm{V}$ \\
\hline 5 & -0.71 & -0.63 & -0.67 & -1.16 & -1.09 & $-1,12$ \\
\hline 10 & -0.74 & -0.6 & -0.67 & -1.18 & -1.07 & $-1,12$ \\
\hline 20 & -0.77 & -0.58 & -0.67 & -1.2 & -1.03 & $-1,12$ \\
\hline 50 & -0.85 & -0.51 & -0.68 & -1.27 & -0.96 & $-1,12$ \\
\hline 100 & -0.97 & -0.42 & -0.69 & -1.35 & -0.87 & $-1,11$ \\
\hline $\begin{array}{c}\text { Extrapolation to } \\
\text { zero scan rate }\end{array}$ & \multicolumn{3}{|c|}{$\mathrm{E}_{\text {red/ox }}, \mathrm{V}(\mathrm{v} \rightarrow 0)$} & \multicolumn{3}{c|}{$\mathrm{E}_{\text {red/ox }}, \mathrm{V}(v \rightarrow 0)$} \\
\hline
\end{tabular}

The comparison of obtained values $E_{\text {red/ox }}$ with the same values for other porphyrins [2-5] allows us to conclude that the pairs of peaks observed belong to one-electron processes of porphyrin electroreduction accompanied mono- and dianion form creation $\left(\mathrm{L}^{-}\right.$and $\left.\mathrm{L}^{2-}\right)$. The lower oxidation potential $(\mathrm{E}=0.25 \mathrm{~V})$ for process III is caused by its chemical structure and the electron-donor ability of methyl and butyl groups.

Additional peaks appeared on the I-E curve (Fig.7) if molecular $\mathrm{O}_{2}$ was present in the solution. 
These peaks correspond to the electroreduction of $\mathrm{O}_{2}$ and peroxide ion creation. The analysis of the current ratio corresponding to these two stages showed that after 30 minutes of $\mathrm{O}_{2}$ bubbling the electrolyte is saturated with oxygen and the equilibrium concentrations of the components in solution are established.

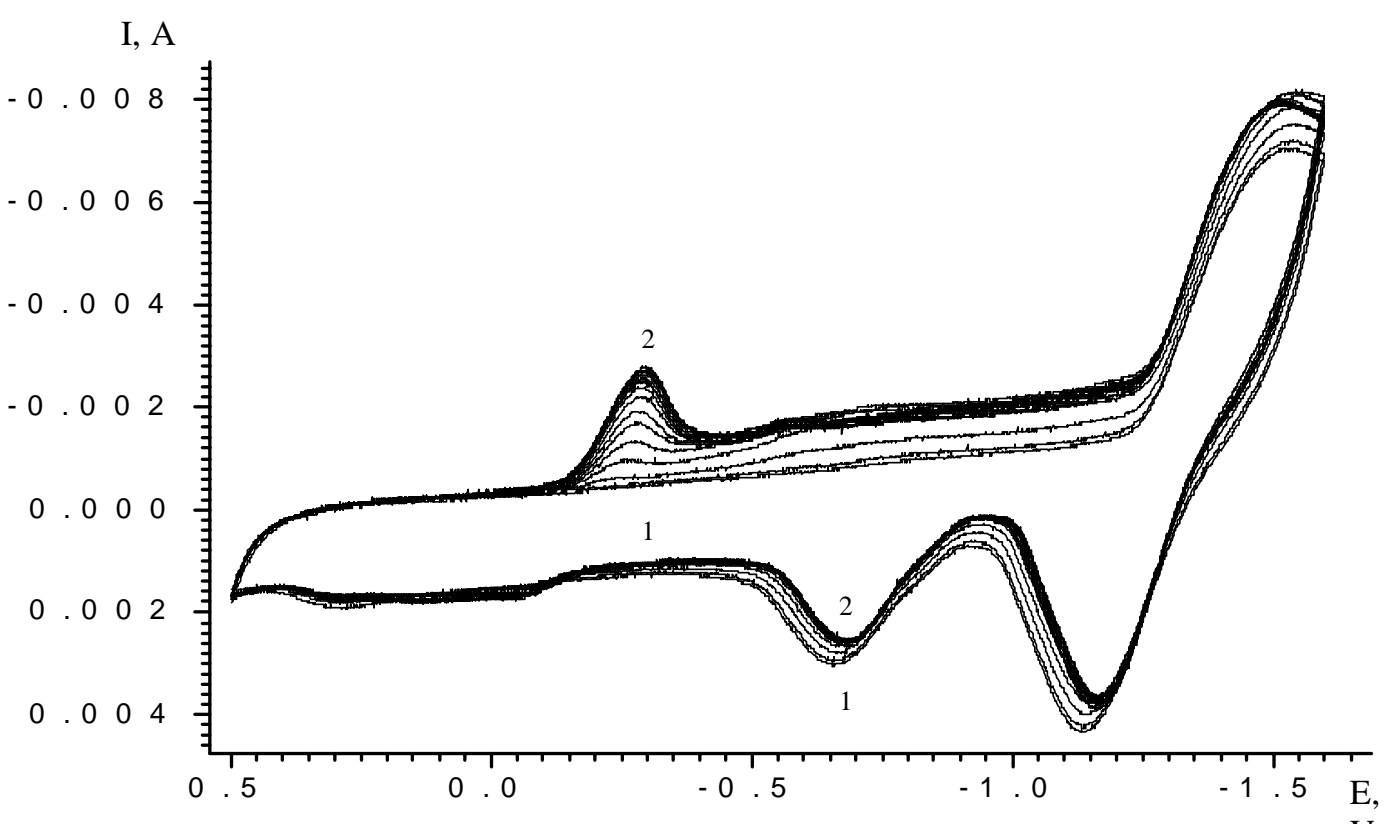

Figure 7. Cyclic voltammogram when molecular $\mathrm{O}_{2}$ has been added to the electrolyte.Scan rate $20 \mathrm{mV} / \mathrm{s}$.

The increasing $\Delta \mathrm{I}_{\mathrm{O} 2} / \Delta \mathrm{I}_{\mathrm{HO} 2}{ }^{-}$ratio manifests itself about 10 cycles after start of scanning, and this fact testifies to the growth of the contribution of direct electroreduction process of dioxygen (Table 2). Starting with the 10th cycle the ratio of the currents corresponding to the first and second stadium of molecular oxygen electroreduction is nearly a constant value.

Table 2. Current values after different numbers of scans for the molecular oxygen transformation process.

\begin{tabular}{|c|c|c|c|c|}
\hline Cycle N & $\begin{array}{c}\text { Scan time } \\
(\min )\end{array}$ & $\begin{array}{c}\operatorname{Imax}(\mathrm{A}) \\
(\mathrm{E}=-0.25 \mathrm{~V})\end{array}$ & $\begin{array}{c}\operatorname{Imax}(\mathrm{A}) \\
(\mathrm{E}=-0,65 \mathrm{~V})\end{array}$ & $\begin{array}{c}\text { Ratio Imax }(\mathrm{E}=-0.25 \mathrm{~V}) / \\
/ \operatorname{Imax}(\mathrm{E}=-0.65 \mathrm{~V})\end{array}$ \\
\hline 4 & 14 & -0.00027262 & -0.000460787 & 0,5916 \\
\hline 6 & 21 & -0.000881274 & -0.00111063 & 0,7935 \\
\hline 8 & 28 & -0.001345321 & -0.001141448 & 1,1786 \\
\hline 10 & 35 & -0.001676613 & -0.000860531 & 1,9484 \\
\hline 15 & 52,5 & -0.001865077 & -0.000974913 & 1,913 \\
\hline 20 & 70 & -0.001937914 & -0.000930405 & 2,083 \\
\hline
\end{tabular}




\section{Experimental}

\section{General}

The porphyrin studied (structure shown below) was synthesized and identified as follows: a solution of 5,5 'dicarboxy-4,4`-dimethyl-3,3`-dibutyl-2,2`-dipyrrolylmethane $(0.5 \mathrm{~g}, 1.04 \mathrm{mmol})$, triethyl orthoformate $(1 \mathrm{~mL}, 6.24 \mathrm{mmol})$ and trifluoracetic acid $(1 \mathrm{~mL})$ in chloroform $(50 \mathrm{~mL})$ was refluxed for 4 hours. The acid was neutralized with ammonia solution. The product was purified by column chromatography $\left(\mathrm{Al}_{2} \mathrm{O}_{3}, \mathrm{CHCl}_{3}\right)$. Yield $133 \mathrm{mg}(36 \%) . \mathrm{R}_{\mathrm{f}}=0.49$ (Silufol, toluene). Electron Absorption Spectrum $\left(\mathrm{CHCl}_{3}\right) \lambda_{\text {max }}, \mathrm{nm}(\lg \varepsilon): 620.3$ (3.62), 566.9 (3.72), 534 (3.90), 498.0 (4.00), 400.1 (5.08); IRspectrum $\left(\mathrm{KBr}\right.$ disk), $\mathrm{cm}^{-1}: v_{\mathrm{NH}}=3335, \delta_{\mathrm{NH}}=960, \gamma_{\mathrm{NH}}=690, v_{\mathrm{CH}}=990, \delta_{\mathrm{CH}}=1480, \gamma_{\mathrm{CH}}=840 ;$ NMRspectrum $\left(\mathrm{CDCl}_{3}\right.$, int. stand. HMDS), $\delta$ (m.d.): 9.91 singlet $(4 \mathrm{H}$, mezo-H), 3.92 triplet $(8 \mathrm{H}$, $\left.\underline{\mathrm{CH}}_{2} \mathrm{CH}_{2} \mathrm{CH}_{2} \mathrm{CH}_{3}\right), 3.47$ singlet $\left(12 \mathrm{H}, \beta-\mathrm{CH}_{3}\right), 2.19$ pentet $\left(8 \mathrm{H}, \mathrm{CH}_{2} \underline{C H}_{2} \mathrm{CH}_{2} \mathrm{CH}_{3}\right), 1.64$ sextet $(8 \mathrm{H}$, $\left.\mathrm{CH}_{2} \mathrm{CH}_{2} \mathrm{CH}_{2} \mathrm{CH}_{3}\right), 1.11$ triplet $\left(12 \mathrm{H}, \mathrm{CH}_{2} \mathrm{CH}_{2} \mathrm{CH}_{2} \mathrm{CH}_{3}\right),-3.82$ singlet $(2 \mathrm{H}, \mathrm{NH}) \mathrm{C}, \mathrm{H}, \mathrm{N}$ analysis: found, \%: C-81.20; H-9.13; N-9.62; calculated for $\mathrm{C}_{40} \mathrm{H}_{54} \mathrm{~N}_{4}$, \%: C-81.22; H-9.14; N-9.64.

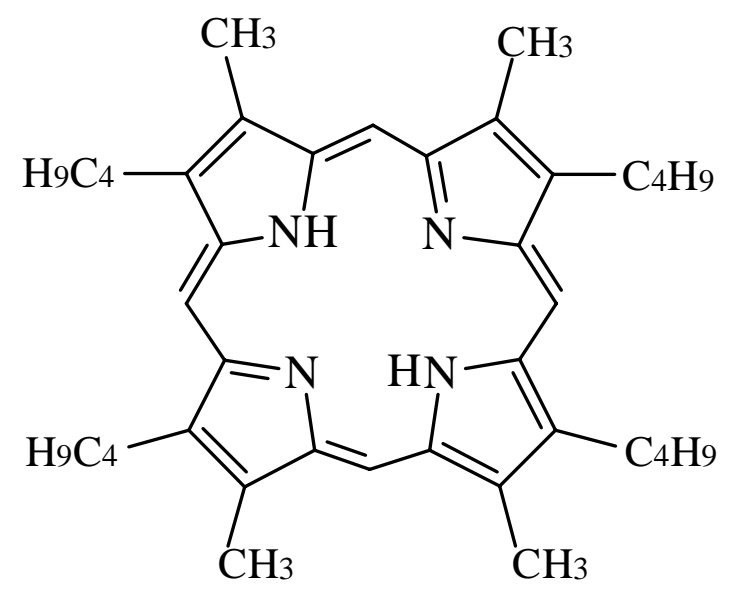

The electrochemical measurements were performed using a standard three-compartment electrochemical cell in $0,1 \mathrm{M} \mathrm{KOH}$ electrolyte [10]. The potential values were measured vs. a $\mathrm{Ag} / \mathrm{AgCl}(\mathrm{sat}$.) reference electrode.

\section{References and Notes}

1. Tarasevich, M. R.; Radiushkina, K. A. Kataliz i elektrokataliz s metallporfirinami; Nauka: Moscow, 1982; 168.

2. Askarov, K.A. Porfiriny: spektroskopiya, elektrohimiya, primenenie; Nauka: Moscow, 1987; 384.

3. Mairanovskii, V.G.; Mamaev, V. M.; Ponomarev, G. V. Russ. J. General Chem. 1974, 44, 2508.

4. Worthington, P.; Hambright, H.; Williams, R. J. Inorg. Biochem. 1980, 12, 281.

5. Girandeau, A.; Ezhar, I.; Gross, M. Bioelectrochem. and Bioenerg. 1976, 3, 519. 
6. Bazanov, M. I. Izv. Vuzov. Himiya i him. Tehnologiya 1988, 31, 62.

7. Bazanov, M. I. Izv. Vuzov. Himiya i him. Tehnologiya 1988, 31, 16.

8. Martynov, N. P.; Bazanov, M. I.; Kolesnikov, N. A. Izv. Vuzov. Himiya i him. Tehnologiya 1995, 38, 97.

9. Bazanov, M. I.; Siling, S. A.; Smirnov, R. P. Elektrohimiya 1996, 32, 1120.

10. Bazanov, M.I.; Ulitina, O.E.; Tiana, J. Elektrohimiya 1999, 35, 212.

Sample Availability: Available from the authors.

(C) 2000 by MDPI (http://www.mdpi.org). Reproduction is permitted for noncommercial purposes. 